\title{
Failure of cerebral autoregulation as a cause of brain dysfunction in the elderly
}

\author{
L WOLLNER, S T McCARTHY, N D W SOPER, D J MACY
}

British Medical fournal, 1979, 1, 1117-1118

\section{Summary and conclusions}

Cerebral blood flow in relation to change in arterial pressure was measured in 11 elderly patients with postural hypotension. Seven patients with symptoms showed bilateral or unilateral failure of cerebral autoregulation, while the four asymptomatic patients did not. Variations in cerebral autoregulation would explain why some elderly people with minor falls of systemic arterial pressure develop clinical signs of cerebral ischaemia whereas others with greater falls in blood pressure remain asymptomatic.

Elderly patients with impaired autoregulation may be at risk of brain damage from minor falls in blood pressure.

\section{Introduction}

In normal subjects the cerebral circulation has a substantial capacity for autoregulation. When systemic arterial pressure falls cerebral vessels dilate so that cerebral blood flow is not reduced until mean arterial pressure falls below $60 \mathrm{~mm} \mathrm{Hg}{ }^{1}$ Some elderly patients with postural hypotension develop clinical signs of cerebral ischaemia with minor falls in systemic arterial pressure which would not produce a change in cerebral blood flow in normal younger subjects. This suggests that these patients may have a defect in cerebral autoregulation.

\section{Patients and methods}

Seven symptomatic patients and four asymptomatic patients with postural hypotension (aged 65-90 years; see table) were studied together with four controls. The controls were three healthy younger men (aged 26-36) and one healthy elderly man (aged 86). All patients with postural hypotension had a fall in blood pressure of more than $20 \mathrm{~mm} \mathrm{Hg}$ systolic and more than $10 \mathrm{~mm} \mathrm{Hg}$ diastolic on standing from the horizontal position. Symptoms of cerebral ischaemia included giddiness, faintness, blackouts, and confusional states. None of the patients or controls received drugs which could affect the arterial blood pressure or cerebral blood flow. All subjects had a normal packed cell volume. Informed consent was obtained from all patients and their relatives.

Cerebral blood flow (CBF) was measured by the method of Mallett and $\mathrm{Veal}^{2}$ as modified by Obrist $e t \mathrm{al}^{3}$ using inhalation of xenon-133, or by the method of Agnoli et al ${ }^{4}$ using xenon-133 by intravenous injection. $5 \mathrm{mCi}$ of xenon-133 in 5 litres of air was used for the inhalation method and $3 \mathrm{mCi}$ of xenon-133 for the intravenous injection method; these doses were approved by the isotope advisory panel. Clearance curves were recorded using sodium iodide detectors, $5 \mathrm{~cm}$

\footnotetext{
Department of Geriatric Medicine, Churchill Hospital, Oxford OX3 7LJ

L WOLLNER, MB, FRCP, consultant physician

S T MCCARTHY, MA, MRCP, consultant physician

Department of Radiation Physics, Churchill Hospital, Oxford OX3 7LJ

N D W SOPER, BSC, ARCS, physicist

D J MACEY, BSC, PHD, physicist
}

in diameter and $3 \mathrm{~mm}$ thick with a parallel hole collimator and $2 \mathrm{~cm}$ of collimation centred over the temporal areas. Single-channel analysers were set out on the $80 \mathrm{keV}$ photopeak of xenon with a window of $32 \mathrm{keV}$. Xenon-133 in expired air was measured with a third counter. The end-expiratory carbon dioxide level (in air) was recorded continuously by an infrared analyser (Capnograph).

The systemic arterial pressure was recorded automatically by a non-invasive technique using the Roche Arteriosonde and a WW recorder. Systolic and diastolic blood pressures, checked at intervals by the aural ausculatory method, did not vary by more than $5 \mathrm{~mm} \mathrm{Hg}$ from the automatic recorded results. The mean arterial blood pressure (MABP) was calculated as the diastolic pressure plus one-third of the pulse pressure. Patients and controls were studied on a tilting bed both in the horizontal and $75^{\circ}$ feet-down positions.

Mean CBF of each hemisphere was calculated from the xenon-133 clearance curves by the initial log slope method. ${ }^{5} \mathrm{~A}$ difference of $10 \%$ in the same hemisphere was considered to be significant. ${ }^{6}$

\section{Results}

Of the seven patients with postural hypotension and symptoms, four had bilateral failure of autoregulation: their mean CBF fell by $32-67 \%$, and MABP fell $9-33 \mathrm{~mm} \mathrm{Hg}$ with change in posture (see table). The remaining three patients had a fall in MABP of 8-12 mm $\mathrm{Hg}$ with change in posture. Mean CBF in one hemisphere fell $22-49 \%$, while in the other hemisphere there was no significant change.

In the four asymptomatic patients MABP fell $10-31 \mathrm{~mm} \mathrm{Hg}$ with change in posture; but there was no significant change in mean $\mathrm{CBF}$, even in the patient whose MABP fell to $54 \mathrm{~mm} \mathrm{Hg}$ (see table).

The four controls showed normal blood pressure responses to a change in posture and no significant change in $\mathrm{CBF}$.

\section{CONTROLS}

The end-expiratory $\mathrm{CO}_{2}$ did not alter more than $0.3 \%$ with change in posture in any of the patients or controls.

\section{Discussion}

The elderly patients with postural hypotension and symptoms showed bilateral or unilateral failure of cerebral autoregulation which was not found in asymptomatic elderly patients.

The metabolic control of cerebral blood flow is mainly by arterial $\mathrm{PCO}_{2}$ and $\mathrm{pH}$, a fall in $\mathrm{PCO}_{2}$ causing vasoconstriction and a rise vasodilatation. There is increasing evidence that sympathetic pathways from the brain to the cerebral blood vessels must be intact for normal autoregulation to occur. ${ }^{7-9}$ Failure of cerebral autoregulation has been described in some patients with autonomic dysfunction, ${ }^{9-12}$ but not in others. ${ }^{13} 14$ Impaired autonomic function is common in the elderly, ${ }^{16}$ and blocked autonomic reflexes might therefore be the cause of both postural hypotension and failure of cerebral autoregulation in some elderly patients. ${ }^{16}$

Unilateral failure of cerebral autoregulation has been shown after experimental occlusion of the middle cerebral artery, ${ }^{17} 18$ and this may remain up to three years. ${ }^{19}$ In patients who have suffered an acute stroke autoregulation may also be impaired in the affected hemisphere. ${ }^{620}{ }^{21}$ Fazekas and Alman hiave suggested that when this occurs cerebral vessels are already maximally dilated on the side where the circulation is compromised by the effect of ischaemic cerebral vascular disease. ${ }^{22}$ Even a minor fall in perfusion pressure may then result in a fall in cerebral blood flow. ${ }^{23}$ 
Changes in mean arterial blood pressure $(M A B P)$ and cerebral blood-flow $(C B F)$ with change in posture in patients with postural hypotension and controls

\begin{tabular}{|c|c|c|c|c|c|c|c|c|c|}
\hline & \multirow[b]{2}{*}{$\begin{array}{l}\text { Case } \\
\text { No }\end{array}$} & \multirow[b]{2}{*}{ Age } & \multirow[b]{2}{*}{ Sex } & \multicolumn{2}{|c|}{$\begin{array}{c}\text { MABP } \\
(\mathrm{mm} \mathrm{Hg})\end{array}$} & \multicolumn{2}{|c|}{ End-expired $\mathrm{CO}_{2}\left({ }^{0}{ }_{0}\right)$} & \multicolumn{2}{|c|}{$\begin{array}{l}\text { Change in mean CBF } \\
\left({ }^{\circ 1}\right)\end{array}$} \\
\hline & & & & Horizontal & $75^{\circ}$ feet-down & Horizontal & $75^{\circ}$ feet-down & $\begin{array}{c}\text { Right } \\
\text { hemisphere }\end{array}$ & $\begin{array}{c}\text { Left } \\
\text { hemisphere }\end{array}$ \\
\hline \multirow[t]{4}{*}{ Patients with symptoms } & \multicolumn{9}{|c|}{ Bilateral failure of autoregulation } \\
\hline & $\begin{array}{l}1 \\
2 \\
3 \\
4\end{array}$ & $\begin{array}{l}72 \\
78 \\
84 \\
69\end{array}$ & $\begin{array}{l}\mathrm{F} \\
\mathrm{M} \\
\mathrm{F}\end{array}$ & $\begin{array}{r}109 \\
113 \\
88 \\
90\end{array}$ & $\begin{array}{r}94 \\
104 \\
79 \\
57\end{array}$ & $\begin{array}{l}5 \cdot 2 \\
4 \cdot 9 \\
6 \cdot 0 \\
5 \cdot 0\end{array}$ & $\begin{array}{l}5 \cdot 2 \\
5 \cdot 0 \\
5 \cdot 7 \\
5 \cdot 2\end{array}$ & $\begin{array}{l}-59 \\
-53 \\
-45 \\
-43\end{array}$ & $\begin{array}{l}-60 \\
-67 \\
-32 \\
-43\end{array}$ \\
\hline & \multicolumn{9}{|c|}{ Unilateral failure of autoregulation } \\
\hline & $\begin{array}{l}5 \\
6 \\
7\end{array}$ & $\begin{array}{l}65 \\
71 \\
90\end{array}$ & $\begin{array}{l}\mathrm{F} \\
\mathrm{F}\end{array}$ & $\begin{array}{l}82 \\
88 \\
88\end{array}$ & $\begin{array}{l}74 \\
76 \\
78\end{array}$ & $\begin{array}{l}5 \cdot 0 \\
5 \cdot 5 \\
5 \cdot 5\end{array}$ & $\begin{array}{l}5 \cdot 0 \\
5.5 \\
5.7\end{array}$ & $\begin{array}{l}-8 \\
-22 \\
-3\end{array}$ & $\begin{array}{l}-49 \\
-8 \\
-33\end{array}$ \\
\hline \multirow[t]{2}{*}{ Asymptomatic patients } & \multicolumn{9}{|c|}{ Normal autoregulation } \\
\hline & $\begin{array}{r}8 \\
9 \\
10 \\
11\end{array}$ & $\begin{array}{l}77 \\
76 \\
80 \\
84\end{array}$ & $\begin{array}{l}F \\
F \\
F\end{array}$ & $\begin{array}{r}114 \\
130 \\
66 \\
64\end{array}$ & $\begin{array}{r}83 \\
117 \\
55 \\
54\end{array}$ & $\begin{array}{l}5.9 \\
6 \cdot 0 \\
5.6 \\
5.5\end{array}$ & $\begin{array}{l}6 \cdot 0 \\
5 \cdot 7 \\
5 \cdot 5 \\
5 \cdot 3\end{array}$ & $\begin{array}{l}-4 \\
-3 \cdot 5 \\
+1 \\
-8\end{array}$ & $\begin{array}{l}\quad 0 \\
+2 \\
+0 \cdot 5 \\
+9\end{array}$ \\
\hline Controls & $\begin{array}{l}12 \\
13 \\
14 \\
15\end{array}$ & $\begin{array}{l}33 \\
26 \\
36 \\
86\end{array}$ & $\begin{array}{l}M \\
M \\
M \\
M\end{array}$ & $\begin{array}{l}94 \\
93 \\
93 \\
85\end{array}$ & $\begin{array}{l}94 \\
89 \\
90 \\
83\end{array}$ & $\begin{array}{l}5 \cdot 6 \\
5 \cdot 7 \\
5 \cdot 7 \\
5 \cdot 2\end{array}$ & $\begin{array}{l}5 \cdot 7 \\
5 \cdot 6 \\
5 \cdot 6 \\
5 \cdot 2\end{array}$ & $\begin{array}{l}-4 \\
+5 \\
+2 \\
-3\end{array}$ & $\begin{array}{l}+10 \\
+2 \\
+4 \\
+6\end{array}$ \\
\hline
\end{tabular}

Postural hypotension is commonly found both in hospital inpatients with symptoms ${ }^{24}$ and asymptomatic elderly patients living in the community. ${ }^{25}$ Variations in cerebral autoregulation would explain why some elderly people with minor falls of systemic arterial pressure develop clinical signs of cerebral ischaemia, whereas others with greater falls in blood pressure remain asymptomatic. They may also explain why transient cerebral dysfunction is common in elderly patients with cardiac dysrhythmias ${ }^{26}$ and the varying effect of hypotensive drugs in the elderly. Elderly patients with impaired cerebral autoregulation may be at risk of brain damage from minor falls in blood pressure.

This work was supported by grants from the Oxford Regional Health Authority and the Oxford Hospital Development and Improvement Fund. We wish to thank Dr J M K Spalding for advice and Dr T Munro and Mr L Fillipow of the department of radiation physics, Churchill Hospital, for help with the measurements of cerebral blood flow.

\section{References}

1 Fieschi, C, and Bozzao, L, in Pharmacology of the Cerebral Circulation, ed A Carpi, vol 1, p 4. Oxford, Pergamon Press, 1972.

2 Mallett, B L, and Veal, N, Clinical Science, 1965, 29, 179.

3 Obrist, W D, et al, Circulation Research, 1967, 20, 124.

4 Agnoli, A, et al, in Cerebral Blood Flow, ed M Brock et al, p 31. Berlin, Springer, 1969.
5 Paulson, O B, et al, fournal of Nuclear Medicine, 1969, 10, 164

${ }^{6}$ Fieschi, C, and Rosiers, M D, in Cerebral Arterial Disease, ed R W Ross Russell, p 85. Edinburgh, Churchill Livingstone, 1976.

7 Purves, M J, Physiology of the Cerebral Circulation, pp 166, 253. London, Cambridge University Press, 1972.

8 Eidelman, B H, et al, Lancet, 1972, 2, 457.

${ }^{9}$ Gotoh, F, et al, European Neurology, 1972, 6, 203.

${ }^{10}$ Meyer, J S, et al, Neurology, 1973, 23, 262.

11 Caronna, J J, and Plum, F, Stroke, 1973, 4, 12.

12 Depresseux, J C, Rousseau, J J, and Franck, G, Acta Neurologica Scandinavica, 1977, 56, Suppl No 64, p 406.

13 Skinhøj, E, Olesen, J, and Strandgaard, S, in Brain and Blood Flow, ed R W Ross Russell, p 351. London, Pitman, 1971.

14 Nanda, R N, et al, in Blood Flow and Metabolism in the Brain, ed A M Harper, et al, p 2. Edinburgh, Churchill Livingstone, 1975.

15 Wollner, L, and Spalding, J M K, Textbook of Geriatric Medicine and Gerontology, ed J C Brocklehurst, p 245. Edinburgh, Churchill Living stone, 1978.

${ }^{16}$ Wollner, L, Age and Aging, 1978, suppl No 7, p 112.

17 Waltz, A G, Ncurology, 1968, 18, 613.

18 Symon, L, Branston, N M, and Strong, A J, Stroke, 1976, 7, 547.

19 Symon, L, et al, Stroke, 1975, 6, 482 .

20 Paulson, O B, Lassen, N A, and Skinhøj, E, Neurology, 1970, 21, 125.

21 Meyer, J S, et al, Stroke, 1973, 4, 169.

${ }^{22}$ Fazekas, J F, and Alman, W R, Archives of Neurology, 1964, 11, 303.

${ }^{23}$ Harper, A M, Journal of Neurology, Neurosurgery, and Psychiatry, 1966, 29, 398.

24 Johnson, $\mathrm{R}$ H, et al, Lancet, 1965, 1, 731.

25 Caird, F I, Andrews, G R, and Kennedy, R D, British Heart fournal, 1973, 35, 527.

${ }^{26}$ McCarthy, S T, and Wollner, L, Lancet, 1977, 2, 202.

(Accepted 2 March 1979)
ONE HUNDRED YEARS AGO The case of a woman in the state of trance, now under the care of Dr Langdon Down in the London Hospital, has excited much interest and presents a well marked example of this condition. The patient is a woman twentyseven years of age, of rather small stature and weak mental capacity. She was admitted on April 3rd on account of symptoms connected with extensive disease of the heart, for which she had been treated as an in-patient in 1877. When admitted, there was marked aphonia she complained of great precordial pain, and frequently expressed her firm idea that "she was going to be married." At this time she had no difficulty in taking liquids; no marked nervous symptoms were present beyond the loss of voice. About May 7th, prostration became marked, without any signs specially attributable to the heartdisease, and she evinced great disinclination to take food of any kind. In a few days, she fell rather suddenly into a state of trance, in which condition she has remained ever since. At first, she could be induced with difficulty to take liquids, but soon she would not swallow even such food, and nutrient enemata had to be given. For a few days, she would reply to questions by monosyllables, but later gave no sign of consciousness, remaining perfectly passive and motionless and could not be roused. There was never any kind of convulsive seizure, local paralysis, or sign of any further lesion connected with the heartdisease; the pulse remained full throughout; the bowels were confined. There was well marked reflex action on touching the conjunctiva; the pupils were of moderate size and active to light. No reflex action was obtained on tickling the feet, and she seemed quite insensible to pricking or pinching the skin. The temperature remained normal. For three days, she was fed by an elastic catheter passed through the nostrils to the pharynx - a proceeding which she made some attempt at resisting. This condition differs from catalepsy in its lifelessness; but for the performance of the organic functions, there is no muscular rigidity, the limbs when raised fall as if lifeless, and, if placed in certain attitudes, are not retained fixed as in catalepsy. At present, the patient remains in the state described, giving no signs of consciousness; her condition appears to be exactly that of the famous Welsh fasting girl, and there is no sign of special disturbance resulting from her heart-disease. For the particulars of this case we are indebted to Dr B Rygate, house-physician. (British Medical fournal, 1879.) 